\title{
School engagement and burnout in a sample of Brazilian students is
}

\author{
Miriane Lucindo Zucoloto ${ }^{\mathrm{a}}$, Vanessa de Oliveira ${ }^{\mathrm{b}}$, João Maroco, $\mathrm{PhD}^{\mathrm{c}}$, \\ Juliana Alvares Duarte Bonini Campos, $\mathrm{PhD}^{\mathrm{a}, *}$ \\ ${ }^{a}$ Faculdade de Odontologia de Araraquara, Departamento de Odontologia Social, Universidade Estadual Paulista \\ "Júlio de Mesquita Filho"-UNESP, Araraquara, São Paulo, Brazil \\ ${ }^{\mathrm{b}}$ Faculdade de Ciências Farmacêuticas de Araraquara, Departamento de Alimentos e Nutrição, Universidade Estadual Paulista "Júlio de \\ Mesquita Filho"-UNESP, Araraquara, São Paulo, Brazil \\ ${ }^{\mathrm{c}}$ Instituto Universitário de Ciências Psicológicas, Sociais e da Vida-ISPA, Lisboa, Portugal
}

\begin{abstract}
Objective: Some studies have suggested that school engagement can be an ally in the prevention of psychosocial and occupational risks, to which students are exposed daily. The aim of this study is to estimate the impact of emotional, behavioral, and cognitive engagement on burnout syndrome among pharmacy undergraduate students.

Methods: A total of 363 students enrolled in the pharmacy undergraduate program in the College of Pharmaceutical Sciences at Sao Paulo State University's Araraquara Campus (UNESP) participated, 78.0\% of whom were female. Mean age was 20.3 $(\mathrm{SD}=2.7)$ years. The Maslach Burnout Inventory for students (MBI-SS) and the University Students School Engagement Inventory (USEI) were used. Confirmatory factor analysis was performed to assess the psychometric properties of the instruments. The data were included in a structural equation model in which burnout was considered the central construct. The impact of school engagement on burnout was based on the statistical significance of causal paths $(\beta)$ evaluated by $z$ tests $(\alpha=5 \%)$.

Results: The psychometric properties of the MBI-SS and USEI were adequate and the structural model also presented an adequate fit. Behavioral engagement $(\beta=-0.56)$ and the emotional engagement $(\beta=-0.71)$ explained $81.0 \%$ of burnout variability in the sample. Cognitive engagement was not found to contribute significantly. This data provides evidence of the impact of school engagement on burnout that can be used by educators and policymakers in charge of educational process. Conclusion: School engagement presented inverse and significant influence on burnout syndrome among pharmacy students. (C) 2016 Elsevier Inc. All rights reserved.
\end{abstract}

Keywords: Professional burnout; School engagement; Students; Education; Pharmacy; Structural equation modeling

\footnotetext{
${ }^{2 / 3}$ This study received funding from the São Paulo Research Foundation-FAPESP (Grant \#2013/09923-4).

* Corresponding author: Juliana Alvares Duarte Bonini Campos, Faculdade de Odontologia de Araraquara, Departamento de Odontologia Social, Universidade Estadual Paulista "Júlio de Mesquita Filho"-UNESP, Araraquara, São Paulo, Brazil.

E-mail: mirianelzucoloto@gmail.com
}

\section{Introduction}

School engagement is a multifactorial construct that can be defined as a positive, fulfilling, and work-related state of mind. ${ }^{1,2}$ There are several definitions of the term "school engagement" in the scientific literature; however, a common point among the main definitions of this construct is the student's "commitment to" and "participation in" the school 
environment. ${ }^{2}$ According to this concept, school engagement can be considered in terms of three factors. The first is behavioral engagement, which is based on students' participation in academic and non-academic school activities and which involves academic engagement, social engagement, and extracurricular activities. The second factor is emotional engagement, which involves positive and negative reactions to peers, professors, and the educational institution itself. This factor is based on the students' affective reactions in the classroom, as well as on their interests, happiness, sadness, and anxiety. Emotional engagement surveys include questions about liking or disliking school, the teacher, and the activities, as well as questions about feelings toward and interests in the school. The third factor is cognitive engagement, which is defined as the psychological investment in learning, a desire to go beyond the requirements, and a preference for challenge, all of which results from the reflection and willpower required to accomplish difficult tasks and develop skills. ${ }^{2,3}$

According to Fredricks et al., ${ }^{2}$ these factors should not be considered separately, but should be applied as a unit so that the factors may interact with each other to provide researchers with a better grasp of the construct. The authors also emphasized that the interaction of these factors is reciprocal and has been found to have a long-term effect on students' achievement. Furthermore, Schaufeli et al. ${ }^{1}$ suggests that school engagement is not a momentary and specific state, but a more persistent and pervasive affectivecognitive state.

Wang et al. ${ }^{3}$ write that the interaction of school engagement factors works synergistically in the learning process. Further, students who exhibit behavioral, emotional, and cognitive engagement with the educational institution and their school subjects are more likely to achieve academic success. In addition, some authors have suggested that school engagement can be an ally in the prevention of psychosocial and occupational risks, to which students are exposed daily. ${ }^{1,2}$ Thus, it is understood that more engaged students exhibit higher academic achievement, more positive feelings about school, teachers, and peers, and are more motivated to develop skills and seek new challenges. As a result, these students cope better with psychosocial and occupational risks created by the school environment. An example of psychosocial and occupational risk in the academic environment is burnout syndrome. ${ }^{1,4,5}$

Burnout is most likely to occur as the result of students' difficulty in coping with common situations experienced in the academic environment. It can be characterized by three factors: emotional exhaustion, cynicism, and inefficacy. ${ }^{6}$ Emotional exhaustion can be understood as feelings of fatigue resulting from academic demands. In this context, cynicism is defined as the development of a detached and impersonal attitude toward study. Professional inefficacy, meanwhile, is characterized by students' feelings of incompetence in relation to their studies.
In previous studies, researchers who investigated burnout syndrome focused their attention on undergraduate students, ${ }^{1,4,5,8,9}$ since, according to Schaufeli et al. ${ }^{1}$ and Campos et al., ${ }^{4}$ burnout can be present while students are still in the initial stages of their professional education. Motivation among researchers to conduct these studies stems from concern about the physical, social, psychological, and academic damages that result from the development of the syndrome or from related symptoms. These consequences, in turn, may prevent students from adapting to the school environment and to experience losses in future professional performance. ${ }^{10}$

Although several studies on burnout among undergraduate students studying medicine, ${ }^{11-13}$ dentistry, ${ }^{4,8}$ and nursing ${ }^{14,15}$ in Brazil can be found in the literature, few studies have investigated burnout among pharmacists or pharmacy students in world scientific literature. ${ }^{16-19}$ Barnett et al. ${ }^{16}$ and Lahoz and Mason ${ }^{17}$ reported the first results on the prevalence of burnout syndrome among pharmacists. These authors detected moderate levels of burnout in their samples. In pharmacy students more specifically, Ried et al. ${ }^{18}$ investigated and compared burnout levels and the predictors of the syndrome among pharmacy students from two university campuses (the founding campus and one of its satellite campuses). The authors reported the student's year of enrollment in the program to be the main predictor of burnout. Campus assignment was also found to be significant for emotional exhaustion, with the highest levels of burnout occurring on the founding campus. Thus, given the shortage of studies, the present study can contribute to the information available on burnout syndrome in different areas and therefore aid in decision making on prevention and intervention settings.

Furthermore, the relation between burnout syndrome and school engagement is also poorly investigated. Although school engagement is considered the opposite of burnout, ${ }^{1}$ this relationship preserving the latent characteristics of these variables is infrequent in the scientific literature.

While similar research has been performed, our study focused on providing data with adequate validity and reliability in order to improve the quality of the estimates and to properly consider the contribution of school engagement to burnout syndrome among pharmacy students for the first time in the literature. This study was conducted to investigate the effects of emotional, behavioral, and cognitive engagement on burnout scores among students enrolled in a pharmacy undergraduate program available in Brazil.

\section{Methods}

\section{Study Design and Sampling}

A cross-sectional study with a non-probabilistic sampling design was developed. The minimum sample size was estimated based on the proposals by Hair et al. ${ }^{20}$ and Kim, ${ }^{21}$ who suggest the use of 5-10 subjects per item/parameter 
evaluated in the structural model. Thus, we estimated a sample size between 185 and 370 subjects.

All students enrolled in the pharmacy undergraduate program within the College of Pharmaceutical Sciences at São Paulo State University's Araraquara Campus-UNESP in 2013 and 2014 were invited to participate $(n=430)$. Of these, 363 agreed to participate, $78.0 \%$ of whom were female. The average age of the participants was $20.3(\mathrm{SD}=$ $2.7)$ years. These proportions and demographics are representative of the study population.

Additional information about socioeconomic class, year in school, class schedule, first choice of the program, expectations about the program, use of medications, and thoughts about dropping out of the program were collected in order to characterize the sample. The socioeconomic classes were classified according to the Brazilian government's Economic Classification Criteria (ABEP). ${ }^{22}$

\section{Measuring Instruments}

To evaluate burnout syndrome, the Portuguese version of the Maslach Burnout Inventory Student Survey (MBISS) was used. This instrument was validated for use on undergraduate students in a previous study conducted by Campos and Maroco ${ }^{7}$ and it is the most commonly used instrument worldwide in the assessment of burnout syndrome. ${ }^{6}$

The MBI-SS relies on a three-factor scale (exhaustion, cynicism, and professional efficacy) and consists of 15 items. The categorical responses of which are arranged on a seven-point rating scale ranging from never (score of 0 ) to always (score of 6 ). ${ }^{23}$

School engagement was estimated using the reduced version of the University Student Engagement Inventory (USEI). ${ }^{2}$ This version is composed of 15 items distributed among three categories called "behavioral engagement," "emotional engagement," and "cognitive engagement." The response categories are arranged along a five-point rating scale ranging from never (score of 0 ) to always (score of 4).

\section{Procedures}

Students completed the questionnaires independently in the classroom during normal school hours on dates that had been scheduled with the teachers responsible for the courses in the pharmacy undergraduate program. The questionnaires were identified by only a participation number in order to preserve participants' anonymity.

\section{Analysis of the Psychometric Properties of the Instruments}

When psychometric scales are used (USEI and MBI-SS), the psychometric properties of the sample must be evaluated. This step is important for assessing the validity and reliability of the instruments and, consequently, for determining the quality of data obtained. ${ }^{24}$ To study these psychometric characteristics of the instruments (MBI-SS and USEI), the sensitivity of the items was evaluated through measures of central tendency, variability, and shape of the distribution. The recommended absolute values of Kurtosis $(|\mathrm{Ku}|<7)$ and Skewness $(|\mathrm{Sk}|<3)$ presented no severe deviations from normality, a result which is indicative of psychometric sensitivity. ${ }^{25}$

Construct validity was assessed using factorial, convergent, and discriminant validity. Factorial validity was assessed via confirmatory factor analysis (CFA) using the method of maximum likelihood. It should be noted that the use of confirmatory factor analysis was based on the fact that the factorial structure of these instruments was defined by a previously established theoretical model. Thus, the confirmatory technique was used to determine the suitability of this theoretical proposal for the data obtained in the study sample. ${ }^{24}$ The goodness of fit indices used to assess the fit of the model included the ratio of chi-square to degrees of freedom $\left(\chi^{2} / \mathrm{df}\right)$, the comparative fit index (CFI), the goodness of fit index (GFI), and the root mean square error of approximation (RMSEA). ${ }^{25,26}$ The fit of the models was considered adequate when $\chi^{2} / \mathrm{df} \leq 2.0$, when CFI and GFI $\geq 0.90$, and when RMSEA $<0.10 .{ }^{25}$ Convergent validity was assessed based on Fornell and Larcker's proposal, ${ }^{27}$ which recommends the calculation of the average variance extracted (AVE) and composite reliability (CR). An AVE $\geq 0.50$ and a $C R \geq 0.70$ were considered indicative of appropriate convergent validity. ${ }^{25}$ Internal consistency was estimated using the standardized Cronbach's alpha coefficient $(\alpha)$, in which a value $\geq 0.70$ was considered adequate. ${ }^{28}$

\section{Statistical Analysis}

Structural Model. To estimate the contribution of school engagement (independent variable) to burnout (dependent variable), the data were included in a structural equation model in which burnout was the central construct. The model fit was analyzed using the same goodness of fit indices presented previously. The contribution of the independent variable to the central construct was based on the statistical significance of the causal paths $(\beta)$, evaluated with the $z$-test for a significance level of $5 \%{ }^{25}$

All analyses were performed using the IBM SPSS Statistics ${ }^{\circledR}$ software and the IBM SPSS Amos ${ }^{\circledR}$ software (v.21, SPSS Inc., Chicago, IL). This study was approved by the Research Ethics Committee of the College of Pharmaceutical Sciences at São Paulo State University's Araraquara Campus (UNESP). Only those who agreed and who signed the informed consent form were included in the study.

\section{Results}

Students provided information on their year of study in the pharmacy program: $47.4 \%$ of the students were in the first year of the program, $16.3 \%$ were in the second year, $6.6 \%$ were in the third year, and $26.7 \%$ were in the fourth year. Only $3.0 \%$ of students who participated were in the fifth or sixth year of the program; in these years, students 
typically perform mandatory internships outside the university. It should be clarified that students' year in the program was not found to contribute significantly to burnout score $(\beta=0.054, p=0.957)$. For this reason, we analyzed the model without the division of the sample according to the year in the program.

Among the students, $76.0 \%$ belonged to Brazil's A and B socioeconomic classes (upper class and upper-middle class), $72.1 \%$ were full-time students, $84.6 \%$ reported that the pharmacy was their first choice among other programs, $50.6 \%$ classified the program as better or much better than their initial expectations, $37.5 \%$ reported that they had used medication at some point as a result of their college experience, and $52.4 \%$ had considered dropping out at some point.

Table 1 presents the summary measures (mean, median, and standard deviation) and shape measures (skewness and kurtosis) used to assess the psychometric sensitivity of the items in the MBI-SS and the USEI.

Suitable values of skewness and kurtosis were observed for all items of the MBI-SS and USEI, findings that indicate a good approximation to the normal distribution.

Table 2 presents the results from the confirmatory factor analysis (CFA), average variance extracted (AVE), composite reliability $(\mathrm{CR})$, and internal consistency $(\alpha)$ of both instruments.

As the table shows, each instrument exhibited an adequate fit to the data. Convergent validity was adequate for the MBI-SS and was below adequate only for the "behavioral engagement" factor of the USEI. Internal consistency was adequate in all factors in both instruments.

The mean scores for emotional exhaustion, cynicism, and professional efficacy among the participants were 3.30

Table 1

Summary and shape measures for the items of University Student Engagement Inventory (USEI) and the Maslach Burnout Inventory (MBI-SS). Araraquara, 2014

\begin{tabular}{|c|c|c|c|c|c|c|}
\hline Factor & Instrument/item & Mean & Median & $\mathrm{SD}^{\mathrm{a}}$ & Skewness & Kurtosis \\
\hline & USEI & & & & & \\
\hline \multirow{5}{*}{$\begin{array}{l}\text { Behavioral } \\
\text { engagement }\end{array}$} & It 1 . Pay attention in class & 2.51 & 3 & 0.83 & -0.62 & -0.07 \\
\hline & It 3 . Follow the school's rules & 3.20 & 3 & 0.81 & -0.98 & 1.18 \\
\hline & It 4 . Do the homework on time & 2.47 & 3 & 1.09 & -0.32 & -0.62 \\
\hline & It 5. Ask questions and participate in debates & 1.89 & 2 & 1.10 & 0.20 & -0.68 \\
\hline & It 6. Participate actively in group assignments & 2.83 & 3 & 0.88 & -0.57 & 0.07 \\
\hline \multirow{5}{*}{$\begin{array}{l}\text { Emotional } \\
\text { engagement }\end{array}$} & It 14 . Do not feel very accomplished at school & 1.34 & 1 & 1.11 & 0.50 & -0.56 \\
\hline & It 15 . Feel excited about the school work & 2.32 & 2 & 1.00 & -0.08 & -0.44 \\
\hline & It 16. Like being at school & 2.51 & 3 & 1.04 & -0.32 & -0.45 \\
\hline & It 17 . Interest in the school work & 2.47 & 2 & 0.98 & -0.21 & -0.46 \\
\hline & It 19. Classroom is an interesting place & 2.01 & 2 & 1.10 & -0.08 & -0.82 \\
\hline \multirow[t]{6}{*}{ Cognitive } & It 22. Self questioning about understand the readings & 2.48 & 3 & 1.14 & -0.29 & -0.81 \\
\hline & It 25 . Talk to other people on matters that I learned in class & 2.29 & 2 & 1.05 & 0.03 & -0.77 \\
\hline & It 26 . Try to solve problems when do not understand the meaning of a word & 2.76 & 3 & 1.07 & -0.50 & -0.61 \\
\hline & It 28 . Try to integrate the acquired knowledge in solving new problems & 2.42 & 2 & 1.01 & -0.25 & -0.52 \\
\hline & $\begin{array}{l}\text { It } 32 . \text { Try to integrate subjects from different disciplines into my general } \\
\text { knowledge }\end{array}$ & 2.33 & 2 & 1.11 & -0.20 & -0.71 \\
\hline & MBI-SS & & & & & \\
\hline \multirow[t]{5}{*}{ Exhaustion } & It 1 . Feel emotionally drained by studies & 3.46 & 4 & 1.58 & -0.15 & -0.79 \\
\hline & It 2 . Feel used up at the end of a studies day & 4.00 & 4 & 1.52 & -0.43 & -0.80 \\
\hline & It 3 . Feel tired when wake up in the morning & 3.54 & 4 & 1.70 & -0.30 & -0.90 \\
\hline & It 4 . Studying or attending a class is really a strain & 2.67 & 3 & 1.82 & 0.26 & -1.08 \\
\hline & It 5 . Feel burned out from the studies & 2.97 & 3 & 1.77 & 0.12 & -0.98 \\
\hline \multirow[t]{4}{*}{ Cynicism } & It 6 . Become less interested in the studies & 2.13 & 2 & 2.06 & 0.58 & -1.06 \\
\hline & It 7 . Become less enthusiastic about the studies & 2.07 & 1 & 2.00 & 0.62 & -0.93 \\
\hline & It 8 . Become more cynical about the usefulness of the studies & 2.22 & 2 & 1.97 & 0.46 & -1.07 \\
\hline & It 9. Doubt the significance of the studies & 2.28 & 2 & 1.96 & 0.48 & -1.03 \\
\hline \multirow[t]{6}{*}{ Professional efficacy } & It 10. Can effectively solve the problems of the studies & 3.93 & 4 & 1.44 & -0.33 & -0.76 \\
\hline & It 11 . Believe in a effective contribution to the classes & 2.92 & 3 & 1.77 & 0.11 & -0.97 \\
\hline & It 12. Itself consider a good student & 3.46 & 3 & 1.58 & -0.18 & -0.80 \\
\hline & It 13 . Feel stimulated when achieve study goals & 4.72 & 5 & 1.43 & -1.04 & 0.41 \\
\hline & It 14 . Learn many interesting things in the studies & 4.47 & 5 & 1.41 & -0.72 & -0.20 \\
\hline & It 15. Feel confident in the class & 3.14 & 3 & 1.57 & 0.07 & -0.78 \\
\hline
\end{tabular}

\footnotetext{
${ }^{\mathrm{a}} \mathrm{SD}=$ standard deviation.
} 
Table 2

Factor weights $(\lambda)$, goodness of fit indices of the confirmatory factor analysis (CFA), average variance extracted (AVE), composite reliability (CR), and internal consistency $(\alpha)$ for the Maslach Burnout Inventory (MBI-SS) and for the University Student Engagement Inventory (USEI). Araraquara, 2014.

\begin{tabular}{lll}
\hline Estimate & MBI-SS & USEI \\
\hline$\lambda$ & $0.52-0.97$ & $0.43-0.88$ \\
$\chi^{2} / \mathrm{df}$ & 3.53 & 2.10 \\
$\mathrm{CFI}$ & 0.94 & 0.96 \\
GFI & 0.90 & 0.94 \\
RMSEA & 0.08 & 0.05 \\
AVE & $0.50-0.69$ & $0.34-0.63$ \\
CR & $0.86-0.90$ & $0.71-0.89$ \\
$\alpha$ & $0.85-0.90$ & $0.71-0.89$ \\
\hline
\end{tabular}

$(\mathrm{SD}=1.41), 2.18(\mathrm{SD}=1.74)$, and $3.77(\mathrm{SD}=1.16)$, respectively. When school engagement was considered, the mean scores for behavioral, emotional, and cognitive engagement in the sample were 2.58 (SD = 0.65), 2.13 $(\mathrm{SD}=0.62)$, and $2.45(\mathrm{SD}=0.79)$, respectively. Tables 3 and 4 present the distribution of student responses to the items of the MBI-SS and USEI.
In the questionnaires, some students reported always feeling emotionally drained by studies and feeling exhausted at the end of a school day. In addition, some students believed that they contributed little to the classes they attended. However, a positive outlook toward education was reported by many of the students; most reported feeling stimulated by successfully completing the goal of their studies and most believed they were learning interesting things over the course of their studies.

Few students described the classroom as a place that is always interesting, and few reported asking questions or participating in debates. However, the students were found to be involved overall, particularly because many reported that, "most of the time," they participate actively in group assignments, pay attention in class, follow school rules, and try to integrate the acquired knowledge into the resolution of new problems.

Figure presents the structural model with paths between factors and the standardized contribution of each variable $(\beta)$.

An adequate fit of the model to the data was observed. Behavioral and emotional engagement made significant negative contributions to burnout syndrome, while cognitive engagement exhibited no significant contribution. It is

Table 3

Distribution of the responses of the students for the Maslach Burnout Inventory (MBI-SS) [n (\%)]. Araraquara, 2014.

\begin{tabular}{|c|c|c|c|c|c|c|c|c|}
\hline \multirow{2}{*}{$\begin{array}{l}\text { Instrument/items } \\
\text { MBI-SS }\end{array}$} & \multicolumn{8}{|l|}{ Responses } \\
\hline & Never & $\begin{array}{l}\text { Almost } \\
\text { never }\end{array}$ & Sometimes & Regularly & Often & $\begin{array}{l}\text { Almost } \\
\text { always }\end{array}$ & Always & Total \\
\hline $\begin{array}{l}\text { It } 1 \text {. Feel emotionally drained by } \\
\text { studies }\end{array}$ & $10(2.76)$ & $32(8.84)$ & $65(17.96)$ & $73(20.17)$ & 77 (21.27) & $66(18.23)$ & $39(10.77)$ & $362(100.00)$ \\
\hline $\begin{array}{l}\text { It } 2 \text {. Feel used up at the end of a } \\
\text { studies day }\end{array}$ & $2(0.55)$ & $22(6.09)$ & $49(13.57)$ & $55(15.24)$ & $72(19.95)$ & $96(26.59)$ & $65(18.01)$ & $361(100.00)$ \\
\hline $\begin{array}{l}\text { It } 3 \text {. Feel tired when wake up in the } \\
\text { morning }\end{array}$ & $14(3.92)$ & $42(11.76)$ & $44(12.32)$ & $66(18.49)$ & $67(18.77)$ & $77(21.57)$ & $47(13.17)$ & $357(100.00)$ \\
\hline $\begin{array}{l}\text { It } 4 \text {. Studying or attending a class is } \\
\text { really a strain }\end{array}$ & $39(10.87)$ & $85(23.68)$ & $54(15.04)$ & $60(16.71)$ & $46(12.81)$ & $47(13.09)$ & $28(7.80)$ & $359(100.00)$ \\
\hline It 5 . Feel burned out from the studies & $27(7.59)$ & $60(16.85)$ & $63(17.70)$ & $70(19.66)$ & $55(15.45)$ & $44(12,36)$ & $37(10.39)$ & $356(100.00)$ \\
\hline $\begin{array}{l}\text { It } 6 . \text { Become less interested in the } \\
\text { studies }\end{array}$ & $111(31.18)$ & $66(18.54)$ & $48(13.48)$ & $32(8.99)$ & $26(7.30)$ & $43(12.08)$ & $30(8.43)$ & $356(100.00)$ \\
\hline $\begin{array}{l}\text { It } 7 . \text { Become less enthusiastic about } \\
\text { the studies }\end{array}$ & $107(30.23)$ & $73(20.62)$ & $42(11.86)$ & $41(11.58)$ & $28(7.91)$ & $36(10.17)$ & $27(7.63)$ & (100.00) \\
\hline $\begin{array}{l}\text { It } 8 \text {. Become more cynical about the } \\
\text { usefulness of the studies }\end{array}$ & $98(27.15)$ & $69(19.11)$ & $38(10.53)$ & $62(17.17)$ & $25(6.92)$ & $45(12.47)$ & $24(6.65)$ & $361(100.00)$ \\
\hline $\begin{array}{l}\text { It 9. Doubt the significance of the } \\
\text { studies }\end{array}$ & 85 & $74(20.56)$ & 5.83) & $38(10.56)$ & $39(10.83)$ & $.56)$ & $29(8.05)$ & 100.00) \\
\hline $\begin{array}{l}\text { It } 10 . \text { Can effectively solve the } \\
\text { problems of the studies }\end{array}$ & $3(0.85)$ & 11 & $53(15.01)$ & $72(20.40)$ & $64(18.13)$ & $100(28.33)$ & $50(14.16)$ & $353(100.00)$ \\
\hline $\begin{array}{l}\text { It } 11 . \text { Believe in a effective } \\
\text { contribution to the classes }\end{array}$ & $32(8.86)$ & $56(15.51)$ & $70(19.39)$ & $69(19.12)$ & $52(14.41)$ & $49(13.57)$ & $33(9.14)$ & $361(100.00)$ \\
\hline It 12 . Itself consider a good student & $11(3.08)$ & $30(8.40)$ & $64(17.93)$ & $75(21.01)$ & $67(18.77)$ & $75(21.01)$ & $35(9.80)$ & $357(100.00)$ \\
\hline $\begin{array}{l}\text { It } 13 \text {. Feel stimulated when achieve } \\
\text { study goals }\end{array}$ & $2(0.56)$ & $13(3.63)$ & $14(3.91)$ & $41(11.45)$ & $62(17.32)$ & $80(22.35)$ & $146(40.78)$ & $358(100.00)$ \\
\hline $\begin{array}{l}\text { It } 14 \text {. Learn many interesting things in } \\
\text { the studies }\end{array}$ & $3(0.83)$ & $6(1.66)$ & $28(7.73)$ & $56(15.47)$ & $65(17.96)$ & $96(26.52)$ & $108(29.83)$ & $362(100.00)$ \\
\hline It 15 . Feel confident in the class & $13(3.59)$ & $43(11.88)$ & $76(20,99)$ & $89(24.59)$ & $56(15.47)$ & $58(16.02)$ & $27(7.46)$ & $362(100.00)$ \\
\hline
\end{tabular}


Table 4

Distribution of the responses of the students for the University Student Engagement Inventory (USEI) [ $n$ (\%)]. Araraquara, 2014.

\begin{tabular}{|c|c|c|c|c|c|c|}
\hline Instrument/items & Responses & & & & & \\
\hline USEI & Never & Few times & Sometimes & $\begin{array}{l}\text { Most of } \\
\text { times }\end{array}$ & Always & Total \\
\hline It 1 . Pay attention in class & $3(0.82)$ & $47(12.95)$ & $98(27.00)$ & $193(53.17)$ & $22(6.06)$ & $363(100.00)$ \\
\hline It 3 . Follow the school's rules & $3(0.83)$ & $7(1.95)$ & $50(13.93)$ & $154(42.90)$ & $145(40.39)$ & $359(100.00)$ \\
\hline It 4 . Do the homework on time & $14(3.97)$ & $56(15.86)$ & $99(28.05)$ & $119(33.71)$ & $65(18.41)$ & $353(100.00)$ \\
\hline It 5. Ask questions and participate in debates & $33(9.14)$ & $109(30.19)$ & $114(31.58)$ & $73(20.22)$ & $32(8.87)$ & $361(100.00)$ \\
\hline It 6. Participate actively in group assignments & $3(0.83)$ & $25(6.93)$ & $82(22.71)$ & $170(47.09)$ & $81(22.44)$ & $361(100.00)$ \\
\hline It 14 . Do not feel very accomplished at school & $97(26.87)$ & $118(32.69)$ & $87(24.10)$ & $46(12.74)$ & $13(3.60)$ & $361(100.00)$ \\
\hline It 15. Feel excited about the school work & $12(3.32)$ & $59(16.34)$ & $141(39.06)$ & $101(27.98)$ & $48(13.30)$ & $361(100.00)$ \\
\hline It 16 . Like being at school & $12(3.32)$ & $46(12.75)$ & $116(32.13)$ & $120(33.24)$ & $67(18.56)$ & $361(100.00)$ \\
\hline It 17 . Interest in the school work & $8(2.25)$ & $48(13.48)$ & $124(34.83)$ & $120(33.71)$ & $56(15.73)$ & $356(100.00)$ \\
\hline It 19. Classroom is an interesting place & $32(8.84)$ & $94(25.96)$ & $102(28.18)$ & $107(29.56)$ & $27(7.46)$ & $362(100.00)$ \\
\hline It 22. Self questioning about understand the readings & $15(4.17)$ & $64(17.78)$ & $93(25.83)$ & $110(30.55)$ & $78(21.67)$ & $360(100.00)$ \\
\hline It 25 . Talk to other people on matters that I learned in class & $10(2.78)$ & $78(21.67)$ & $124(34.44)$ & $94(26.11)$ & $54(15.00)$ & $360(100.00)$ \\
\hline $\begin{array}{l}\text { It } 26 . \text { Try to solve problems when do not understand the } \\
\text { meaning of a word }\end{array}$ & $7(1.94)$ & $44(12.19)$ & $85(23.54)$ & $118(32.69)$ & $107(29.64)$ & $361(100.00)$ \\
\hline $\begin{array}{l}\text { It } 28 . \text { Try to integrate the acquired knowledge in solving } \\
\text { new problems }\end{array}$ & $10(2.77)$ & $58(16.06)$ & $114(31.58)$ & $128(35.46)$ & $51(14.13)$ & $361(100.00)$ \\
\hline $\begin{array}{l}\text { It } 32 . \text { Try to integrate subjects from different disciplines } \\
\text { into my general knowledge }\end{array}$ & $19(5.25)$ & $67(18.51)$ & $110(30.39)$ & $108(29.83)$ & $58(16.02)$ & $362(100.00)$ \\
\hline
\end{tabular}

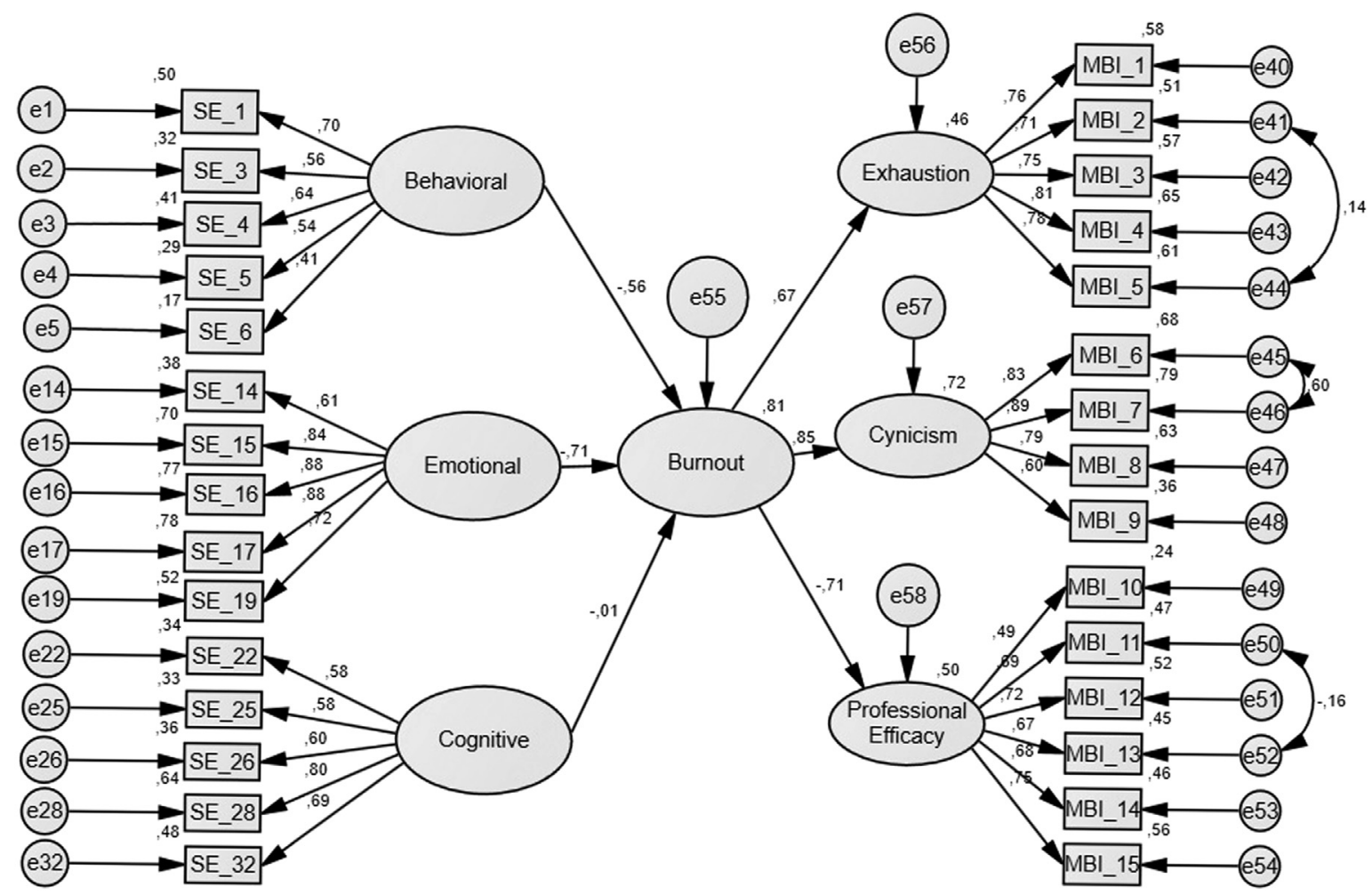

Fig. Structural model to evaluate the contribution of behavioral, emotional, and cognitive engagement to burnout syndrome (SE: School engagement items; MBI: Maslach Burnout Inventory items; e: errors; Model fit: $\mathrm{x}^{2} / \mathrm{df}=3.47$; CFI=0.90; GFI=0.90; RMSEA=0.08). Araraquara, 2014. 
important to note that school engagement explained $81 \%$ of the variability of burnout observed in this study sample.

\section{Discussion}

The model proposed herein for the effects of student engagement on burnout revealed the significant and negative impact of behavioral and emotional engagement on burnout in this sample of pharmacy students. These results support the importance of these variables in protocols for education about, prevention of, and treatment for burnout syndrome.

It is important to note that the mean scores for the three factors of burnout syndrome and school engagement in our study may be considered moderate. These results are consistent with other studies in the literature. ${ }^{3-5}$ However, there is a need for early investigations into burnout among students; these investigations must consider the factors associated with the syndrome. ${ }^{1,4}$ It is important to carefully consider the results presented, as some students reported signs of exhaustion and cynicism, as well as signs of low school engagement (Tables 3 and 4). These signs are frequently the first manifestations of burnout syndrome and should therefore not be ignored.

Although several studies have emphasized the effects of burnout syndrome and school engagement on academic achievement and student well-being, little is known about the relationship between these constructs. ${ }^{1}$ As previously mentioned, some authors, such as Fredricks et al., ${ }^{2}$ suggest that school engagement may protect against the psychosocial and occupational hazards of the academic environment. According to Schaufeli et al., ${ }^{1}$ school engagement may be considered the hypothetical inverse of burnout. As far as we know, this study represents the first report of evidence to support Fredericks and Schaufeli's observations in Brazil.

The model proposed (Fig.) shows a significant and negative relationship between behavioral/emotional engagement and burnout syndrome. Behavioral and emotional engagement explained $50.4 \%$ and $31.4 \%$ of burnout variability, respectively. It is important to highlight the high variance of burnout exhibited by this model (81.0\%). The data provide evidence of the impact of school engagement on burnout that can be used by educators and policymakers in charge of educational processes. The data offer guidance for interventions that can minimize the occurrence of burnout syndrome in the academic environment.

It is also important to repeat that no significant impact of cognitive engagement on burnout syndrome was detected. When defined in general terms, cognition is the way the brain processes, learns, remembers, and thinks about all information captured through the five senses. Cognitive engagement can be understood as the student's psychological investment efforts directed toward learning, understanding, and mastering the knowledge and skills that the academic environment is designed to promote. ${ }^{29}$ It is worth clarifying that "effort" in cognitive engagement is different from that seen in behavioral engagement. ${ }^{2}$ In cognitive engagement, "effort" is focused on learning and mastering the material. Thus, it is characterized by an amount of psychological control that preserves concentration and helps students to avoid distractions, thus facilitating the learning process. $^{30}$ Therefore, it is plausible that the knowledge/ skills developed in the academic environment and the psychological effort required do not have a direct impact on the development of burnout. This lack of an impact differs from the impact of the behaviors and emotions generated by the school environment.

In this study, the validity and reliability of the instruments in the sample were assessed. The data gathered were valid and reliable, ensuring the quality of the model estimates obtained.

The lack of research on the relationship between school engagement and burnout syndrome does not allow for a direct comparison of our results to previous studies. Therefore, we encourage the application of these types of studies on other samples of undergraduate students from different cultural contexts in an attempt to more concretely establish whether school engagement is a relevant factor in burnout syndrome.

The limitations of this study include its cross-sectional study design, which does not allow infer for a cause-andeffect relationship between variables. Another aspect is the limited sample, which includes only students from a single Brazilian university. In addition, there is a possible relationship between students' individual academic performance and the development of burnout, a connection which was not considered in this study. Therefore, we encourage the inclusion of this variable in future studies. Furthermore, broader studies would be important for confirming the model proposed.

\section{Conclusion}

Behavioral engagement and emotional engagement were found to make strong and significant contributions to the reduced development of burnout syndrome in a sample of students enrolled in a pharmacy undergraduate program in Brazil.

\section{Conflicts of interest}

No conflicts of interest.

\section{References}

1. Schaufeli WB, Martínez IM, Pinto AM, Salanova M, Bakker AB. Burnout and engagement in university students. J Cross Cult Psychol. 2002;33(5):464-481.

2. Fredricks JA, Blumenfeld PC, Paris AH. School engagement: potential of the concept, state of the evidence. Rev Educ Res. 2004;74(1):59-109. 
3. Wang MT, Willett JB, Eccles JS. The assessment of school engagement: examining dimensionality and measurement invariance by gender and race/ethnicity. J School Psychol. 2011;49(4):465-480.

4. Campos JADB Jordani PC, Zucoloto ML, Bonafé FSS, Maroco J. Síndrome de Burnout em graduandos de Odontologia. Rev Bras Epidemiol. 2012;15(1):155-165.

5. Carlotto MS, Câmara SG. Preditores da Síndrome de Burnout em estudantes universitários. Pensam Psicol. 2008;4(10): 101-109.

6. Maslach C, Jackson SE, Leiter MP. Maslach Burnout Inventory Manual. 3rd ed., Palo Alto: Consulting Psychologists Press; 1996.

7. Campos JADB, Maroco J. Adaptação transcultural PortugalBrasil do Inventário de Burnout de Maslach para estudantes. Rev Saude Publica. 2012;46(5):816-824.

8. Jordani PC, Zucoloto ML, Bonafé FSS, Maroco J, Campos JADB. Aspectos da vida universitária e a síndrome de burnout. Psychol Community Health. 2012;1(3):246-256.

9. Maroco J, Tecedeiro M. Inventário de Burnout de Maslach para estudantes portugueses. Psicol Saude Doenças. 2009;10(2): 227-235.

10. Nakamura AP, Míguez C, Arce R. Equilibrio psicológico y burnout académico. Rev Invest Educ. 2014;12(1):32-39.

11. Pagnin D, Queiroz V, Oliveira Filho MA, et al. Burnout and career choice motivation in medical students. Med Teach. 2013;35(5):388-394.

12. Costa EFO, Santos SA, Santos ATRA, Melo EV, Andrade TM. Burnout syndrome and associated factors among medical students: a cross-sectional study. Clin Sci. 2012;67(6):573-579.

13. Mori MO, Valente TCO, Nascimento LFC. Síndrome de Burnout e Rendimento Acadêmico em Estudantes da Primeira à Quarta Série de um Curso de Graduação em Medicina. Rev Bras Educ Med. 2012;36(4):536-540.

14. Dalmolin GL, Lunardi VL, Lunardi GL, Barlem ELD, Silveira RS. Sufrimiento moral y síndrome de Burnout: ¿Están relacionados esos dos fenómenos en los trabajadores de enfermería? Rev Latino Am Enfermagem. 2014;22(1):1-8.

15. Silva MT, Magalhães FG. Análise qualitativa da síndrome de Burnout nos enfermeiros de setores oncológicos. ICSA. 2014; 2(2):37-46.
16. Barnett CW, Hopkins WAJ, Jackson RA. Burnout experienced by recent pharmacy graduates of Mercer University. Am J Hosp Pharm. 1986;43(11):2780-2784.

17. Lahoz MR, Mason HL. Burnout among pharmacists. Am Pharm. 1990;30(8):28-32.

18. Ried LD, Motycka C, Mobley C, Meldrum M. Comparing selfreported burnout of pharmacy students on the founding campus with those at distance campuses. Am J Pharm Educ. 2006;70 (5): Article 114.

19. Carlotto MS, Câmara SG. Características psicométricas do Maslach Burnout Inventory-Student Survey (MBI-SS) em estudantes universitários brasileiros. Psico. 2006;11(2):167-173.

20. Hair JF, Black WC, Babin B, Anderson RE, Tatham RL. Multivariate Data Analysis. 6th ed., New Jersey: Prentice Hall; 2005.

21. Kim KH. The relation among fit indexes, power and sample size in structural equation modeling. Struct Equ Model. 2005;12(3):368-390.

22. ABEP, Associação Brasileira de Empresas de Pesquisa. Critério de Classificação Econômica Brasil. 2011.2011

23. Maslach C, Jackson SE. Maslach Burnout Inventory Manual. Palo Alto, University of California: Consulting Psychologist Press; 1986.

24. Anastasi A. Psychological Testing. 6th ed. New York: Macmillan, Collier Macmillan; 1988.

25. Maroco J. Análise de equações estruturais. 2nd ed., Lisboa: ReportNumber; 2014.

26. Kline RB. Principles and Practice of Structural Equation Modeling. . New York: The Guilford Press; 1998.

27. Fornell C, Larcker DF. Evaluating structural equation models with unobservable variables and measurement error. J Marketing Res. 1981;18(1):39-50.

28. Maroco J, Garcia-Marques T. Qual a fiabilidade do alfa de Cronbach? Questões antigas e soluções modernas? Lab Psicol. 2006;4(1):65-90.

29. Newmann FM. Student Engagement and Achievement in American Secondary Schools. New York: Teachers College Press; 1992.

30. Corno L, Mandinach E. The role of cognitive engagement in classroom learning and motivation. Educ Psychol. 1983;18(2): 88-108. 